\title{
Tracking Unicorns: A Multi-Institutional Network Analysis of Library Functional Areas
}

\author{
Emily Guhde \\ Georgetown University, USA \\ Brian Keith \\ University of Florida, USA
}

Libraries and Library Positions in a Period of Change

Libraries have experienced a sustained period of change. Factors including globalization and technology have caused a reconsideration of the research library in terms of physical environment, services, and pervasive technology. ${ }^{1}$ Per Barbara Dewey, the global research library must "address sweeping changes in technology transforming all aspects of creating, disseminating, and accessing scholarship in a multi-cultural world." John Seely Brown advises that we are now in "an era of equilibrium to a new normal that is an era of constant dis-equilibrium.” ${ }^{3}$ Regarding technology, Lori A. Goetsch states:

Technology has significantly influenced how students and faculty use the services and collections of academic libraries. In response, libraries are identifying new roles and responsibilities for librarians by both reinventing more traditional positions as well as creating new job roles that require different skill sets and mind sets. ${ }^{4}$

In response to these factors and others, library leaders are recruiting and reshaping their "workforce through creative approaches to defining and organizing roles, hiring personnel, and deploying and retraining existing staff." ${ }^{5}$

The work of libraries has always been complicated and a comprehensive set of technical, support, and public services must be represented and effectively delivered in order for it to effectively function. But the wave of changes in recent history, along with financial constraints faced by research libraries, has created the phenomenon of the "unicorn job," where a variety of functions and associated requisite skills and knowledge coexist, potentially unrealistically, in one position.

\section{Position Descriptions}

A position description is "an orderly record of the essential activities involved in the performance of a task that is abstracted from a job analysis and used in classifying and evaluating jobs and in the selection and placement of employees." ${ }^{6}$ These commonplace business documents are important for academic libraries on multiple levels, as they reflect "the culture, priorities, and changes within an organization... not only to employees and their departments but also to the academic institution within which the library functions and the profession beyond."7

Position descriptions-and their close relative, the job advertisement-are often a basis for analysis in research, both practical and scholarly, seeking an understanding of library work types, traditional and emerging. The results of these studies appear frequently in library and information science literature. ${ }^{8}$ Some studies focus on the evolving nature of libraries and the requisite skills for new work types: digital librarians; scholarly communication librarians; social science data librarians; instructional design librarians; and emerging technologies librarians. ${ }^{9}$

Therese Triumph and Penny Beile sought to examine "the current state of the academic library job market and identify emerging trends,"10 and found that "academic library jobs are becoming increasingly specialized-and many require new job skills." ${ }^{\text {"L }}$ Lori Goetsch studied job advertisements over a 10-year period and reports: 
Drawing on the core roles and responsibilities of positions such as systems librarians (high-level technological expertise), reference librarians (user assistance and education), and subject librarians (collection development and management and liaison work), a re-envisioned and interrelated set of four new core responsibilities emerges: consulting services; information lifecycle management; collaborative print and electronic collection building; and information mediation and interpretation. ${ }^{12}$

As new responsibilities blend with traditional library functions, the perception emerges that position descriptions are less circumscribed by narrow job functions and instead tend to describe hybrid roles. In considering these hybrid roles, studying the frequency of functional areas, like cataloging and preservation, coexisting within one position (and represented in a single position description) is a reasonable approach. An examination of the occurrences, frequencies, and relationships between these functional areas is akin to studying a social network of multiple groups with overlapping membership. As such, the application of established network analysis methods might provide insight on a field in flux. To the knowledge of the researchers, the principles of a social network analysis have yet to be applied to a large data set of position descriptions. This research could contribute to tracking the emergence of "unicorn jobs" in response to shifting roles and responsibilities in academic libraries.

\section{ARL PD Bank: Background}

In March 2012, the ARL (Association of Research Libraries) Board of Directors authorized the establishment of the ARL PD Bank. ${ }^{13}$ ARL contributed a significant portion of the programming cost for the system, which was developed by a team at the University of Florida (UF) with broad input from other institutions, including over 20 ARL member institutions, via surveys, focus groups, and beta testing. In February 2013, the ARL PD Bank was officially launched. Initially, the PD Bank was only available to ARL members. In order to sustain the community, maximize the collection use, and create an even more comprehensive collection, access was expanded. Beginning in 2014, library consortia that included at least one ARL member institution were permitted to join the ARL PD Bank as a group and, as a result, extend access to their non-ARL members. The first consortium to join was the Association of Southeastern Research Libraries (ASERL). The Canadian Association of Research Libraries (CARL) followed suit in 2015.

The ARL PD Bank was designed as a digital collection of position descriptions and related documents, such as annual assignments and position vacancy announcements, which describe the work of library employees, interns, and other affiliates. The users of this system include library administrative staff involved in personnel management and those who rely on the documents for managerial activities and planning. As a collective work of academic and research libraries in the United States and Canada, the ARL PD Bank provides not only an aggregated source for current PDs, which shows the varied ways in which institutions organize and define functions, but also for archived documents which depict the evolution of positions and library functions and services over time.

\section{Metadata}

The ARL PD Bank was implemented based on a conceptual model of a "repository" or "archive." Its success has relied on the experiences of the UF team with longstanding digital collections. As a shared community platform, the system relies on descriptive metadata for the position records which is submitted and maintained by each institution. Position records are searchable and accessible by the following elements of metadata which the users provide:

- Full-time equivalency (FTE) level;

- Position status (filled, open, or discontinued);

- Position type (professional librarian; support or paraprofessional; other professional; or other);

- Appointment type (regular; tenure accruing or permanent; temporary/time limited; or residency/fellowship/internship);

- Library type (medical library; law library; non-university library; or all other); and

- Functional areas (see Appendix A). 
When a record is initiated by an institutional user, each element of this descriptive metadata is required for submission.

For this study we are focusing on the functional areas which serve the system as classification metadata, supporting "the systematic identification and arrangement of business activities and related records into categories according to logically structured conventions, methods and procedural rules." ${ }^{14}$ For each position record, the submitter identifies, from the controlled vocabulary, all of the functional areas that relate to the substantive duties and responsibilities of the particular position. Depending on the duties of the position, the associated ARL PD Bank record will include one or more functional areas. As a result, functional areas either appear in isolation, for a narrowly focused position, or co-occur with other functional areas. In this research, we assert that the frequency of the co-occurrence or the lack of co-occurrence of functional areas offers a unique perspective into the ways in which library work is organized and the ways in which types of work relate to each other. This capacity is enhanced because the available choices for functional areas are focused and reasonably discrete, and seemingly representative of the full range of library work types. The strength of the metadata and the number of records contained in the system creates a unique data set.

\section{Methodology}

Applying strategies used in social network analysis, we approached the data set as if each position record was an individual who belonged to various social groups. Each position record included in the analysis was associated with any number of functional areas between 1 and 37, and this attribute paralleled a network affiliation. Understanding the functional spread (i.e., how many functions were included in each position record) and measuring the frequency of job functions co-occurring (i.e., how often any two functions occurred together within one position record) was of great interest to the researchers.

Before performing the analysis, we removed any discontinued positions. Next, by using the Position Type and functional area data, we separated the remaining position records into three groups: professional positions, support positions, and management positions. This process is depicted in Table 1:

\section{Table 1: Breakdown of position records into analysis groups}

\begin{tabular}{|l|l|l|l|}
\hline Group & Included & Excluded & $\begin{array}{l}\text { Total position records } \\
\text { included in analysis }\end{array}$ \\
\hline $\begin{array}{l}\text { Professional } \\
\text { Positions }\end{array}$ & $\begin{array}{l}\text { Position Type } \\
\text { Professional Librarians } \\
\text { or Other Professionals }\end{array}$ & $\begin{array}{l}\text { Any record with } \\
\text { Branch/Unit/Department } \\
\text { Management or Senior } \\
\text { Management indicated in the } \\
\text { functional area field }\end{array}$ & 564 \\
\hline $\begin{array}{l}\text { Support } \\
\text { Positions }\end{array}$ & $\begin{array}{l}\text { Position Type = Support } \\
\text { or Paraprofessionals } \\
\text { (non-exempt) or Support } \\
\text { or Paraprofessionals } \\
\text { (exempt only) }\end{array}$ & $\begin{array}{l}\text { Any record with } \\
\text { Branch/Unit/Department } \\
\text { Management or Senior } \\
\text { Management indicated in the } \\
\text { functional area field }\end{array}$ & 713 \\
\hline $\begin{array}{l}\text { Management } \\
\text { Positions }\end{array}$ & $\begin{array}{l}\text { Functional area } \\
\text { Branch/Unit/ } \\
\text { Department Management } \\
\text { or Senior Management }\end{array}$ & $\begin{array}{l}\text { Any record where Branch/Unit/ } \\
\text { Senior Management, or both is } \\
\text { indicated in the functional area } \\
\text { field }\end{array}$ & 165 \\
\hline
\end{tabular}


The data were prepared for input into Gephi using all potential functional areas as nodes and listing out each position record's connections one by one (automated with Excel). This process resulted in two files, one describing the data set's nodes (functional areas) and one describing the data set's edges (connections between functional areas). Once the nodes and edges files were uploaded to Gephi, we ran a multimode networks projection, resulting in a visualization of the functions and their relationships to each other as represented in the data.

\section{Findings}

The graphical output from Gephi shows a complicated web of relationships, in the forms of co-occurrences between job functions (ARL PD Bank functional areas). The size of the node (circle) represents the number of position records associated with that job function. The most common job functions result in the largest nodes. The thickness of the line between nodes represents the frequency of co-occurrence between any two job functions. The greater the instances of co-occurrence, the thicker the line connecting the job function nodes.

\section{Professional Positions}

Figure 1 displays the graphical representation of the network of the functional overlap among the 564 professional position records included in our analysis.

\section{Figure 1: Gephi output of professional position records}

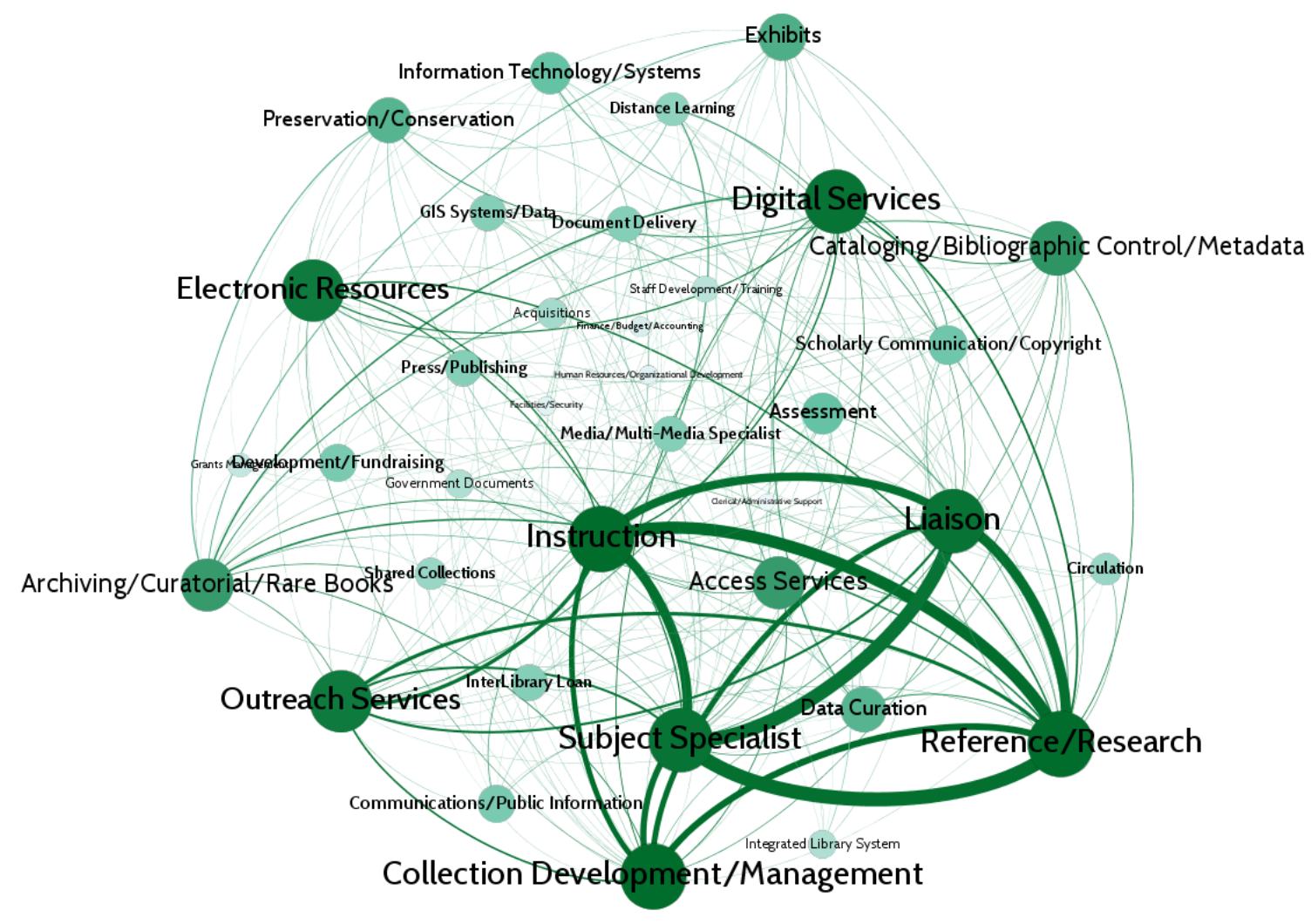

Co-occurrence is the measure of how frequently any two functions were associated within the same position record. The top 5 co-occurrences by count among all 564 professional position records were:

- Reference/Research and Subject Specialist, co-occurring in 86 positions and with this cooccurrence relationship representing $49 \%$ of reference/research positions and $48 \%$ of subject specialist positions. 
- Liaison and Subject Specialist, co-occurring in 85 positions and with this co-occurrence relationship representing $79 \%$ of liaison positions and $47 \%$ of subject specialist positions.

- Instruction and Reference/Research, co-occurring in 74 positions and with this co-occurrence relationship representing $67 \%$ of instruction positions and $41 \%$ of subject specialist positions.

- Liaison and Reference/Research, co-occurring in 62 positions and with this co-occurrence relationship representing $57 \%$ of liaison positions and $35 \%$ of reference/research positions.

- Instruction and Subject Specialist, co-occurring in 59 positions and with this co-occurrence relationship representing $53 \%$ of instruction positions and $33 \%$ of subject specialist positions.

In $50 \%$ of the 564 professional position records included in our analysis, only one job function had been selected. In other words, half of the professional position records analyzed for this study had a singular job focus and half had multiple job functions coexisting (see Graph 1 below).

\section{Graph 1: Professional functional spread}

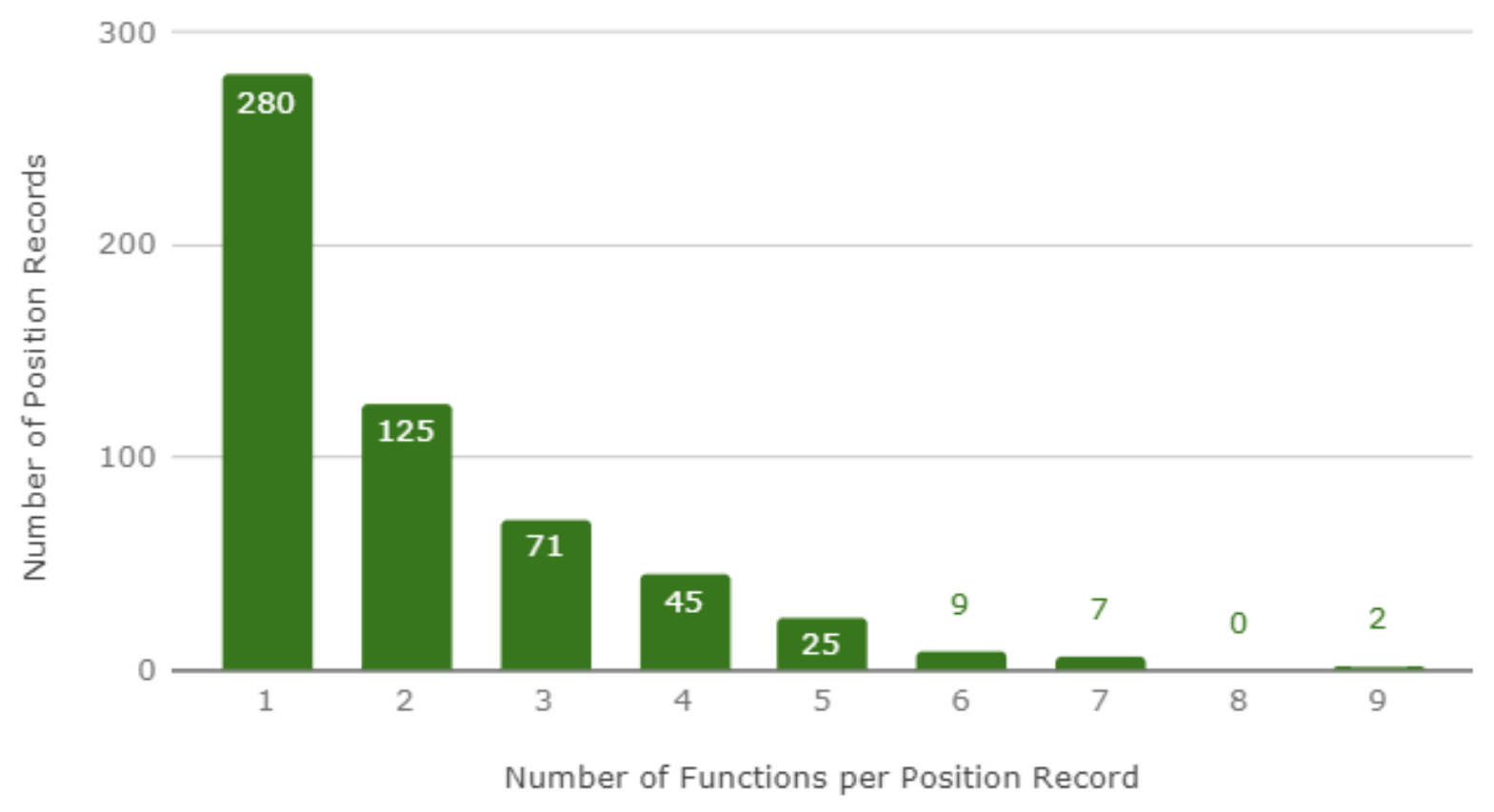

For the professional position records, the job functions in Table 2 were more likely to occur in isolation than to coexist with other functions.

Table 2: Job functions in professional positions more likely to occur in isolation

\begin{tabular}{|l|l|l|}
\hline Function & $\begin{array}{l}\text { \% of professional positions } \\
\text { with functional isolation }\end{array}$ & $\begin{array}{l}\text { Total number of professional } \\
\text { positions associated with function }\end{array}$ \\
\hline Clerical & $100 \%$ & 1 \\
\hline Information Technology & $69 \%$ & 42 \\
\hline Cataloging & $56 \%$ & 61 \\
\hline
\end{tabular}




\begin{tabular}{|l|l|l|}
\hline Function & $\begin{array}{l}\text { \% of professional positions } \\
\text { with functional isolation }\end{array}$ & $\begin{array}{l}\text { Total number of professional } \\
\text { positions associated with function }\end{array}$ \\
\hline Assessment & $54 \%$ & 13 \\
\hline Archiving/Curatorial/Rare Books & $53 \%$ & 70 \\
\hline
\end{tabular}

Notably, no professional position records were associated with the off-site storage function.

\section{Support Positions}

Figure 2 displays the graphical output of the functional overlap among the 713 support position records included in our analysis.

Figure 2: Gephi output of support position records

\section{Communications/Public Information}

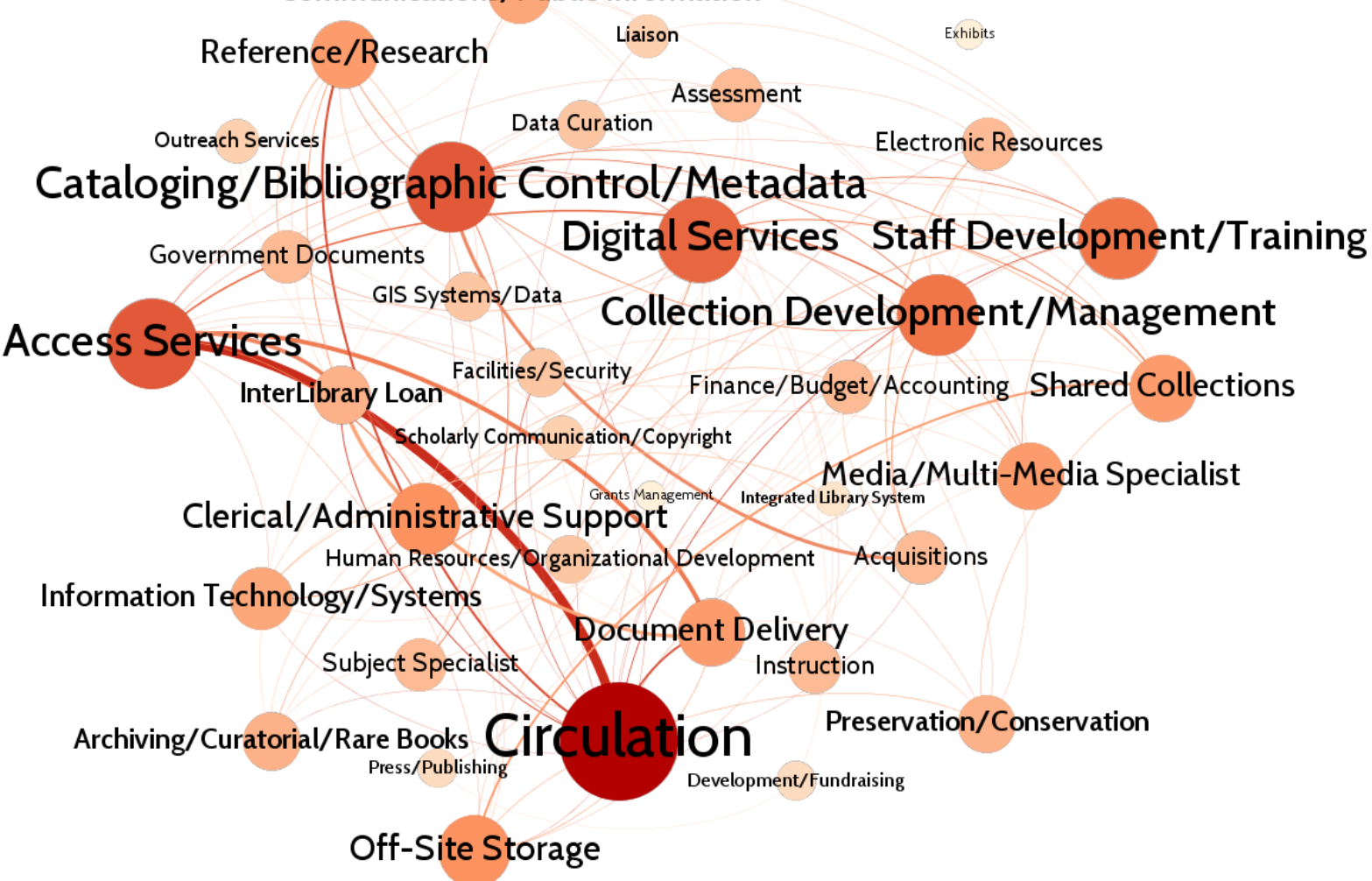

Co-occurrence is the measure of how frequently any two functions were associated with the same position record. The top 5 co-occurrences by count among all 713 support position records were:

- Access Services and Circulation, co-occurring in 32 positions and with this co-occurrence relationship representing $43 \%$ of access services positions and $31 \%$ of circulation positions.

- Access Services and Document Delivery, co-occurring in 15 positions and with this co-occurrence relationship representing $20 \%$ of access services positions and $54 \%$ of document delivery positions.

- Access Services and InterLibrary Loan co-occurring in 14 positions and with this co-occurrence relationship representing $19 \%$ of access services positions and $54 \%$ of ILL positions. 
- Acquisitions and Cataloging/Bibliographic Control/Metadata co-occurring in 12 positions and with this co-occurrence relationship representing $18 \%$ of acquisitions positions and $15 \%$ of cataloguing/bibliographic control/metadata positions.

- Document Delivery and InterLibrary Loan, co-occurring in 12 positions and with this cooccurrence relationship representing $43 \%$ of document delivery positions and $25 \%$ of InterLibrary loan positions.

In $75 \%$ of the support position records included in our analysis, only one job function was indicated. In other words, three quarters of the support position records analyzed for this study had a singular job focus and one quarter had multiple functions coexisting (see Graph 2 below).

\section{Graph 2: Support functional spread}

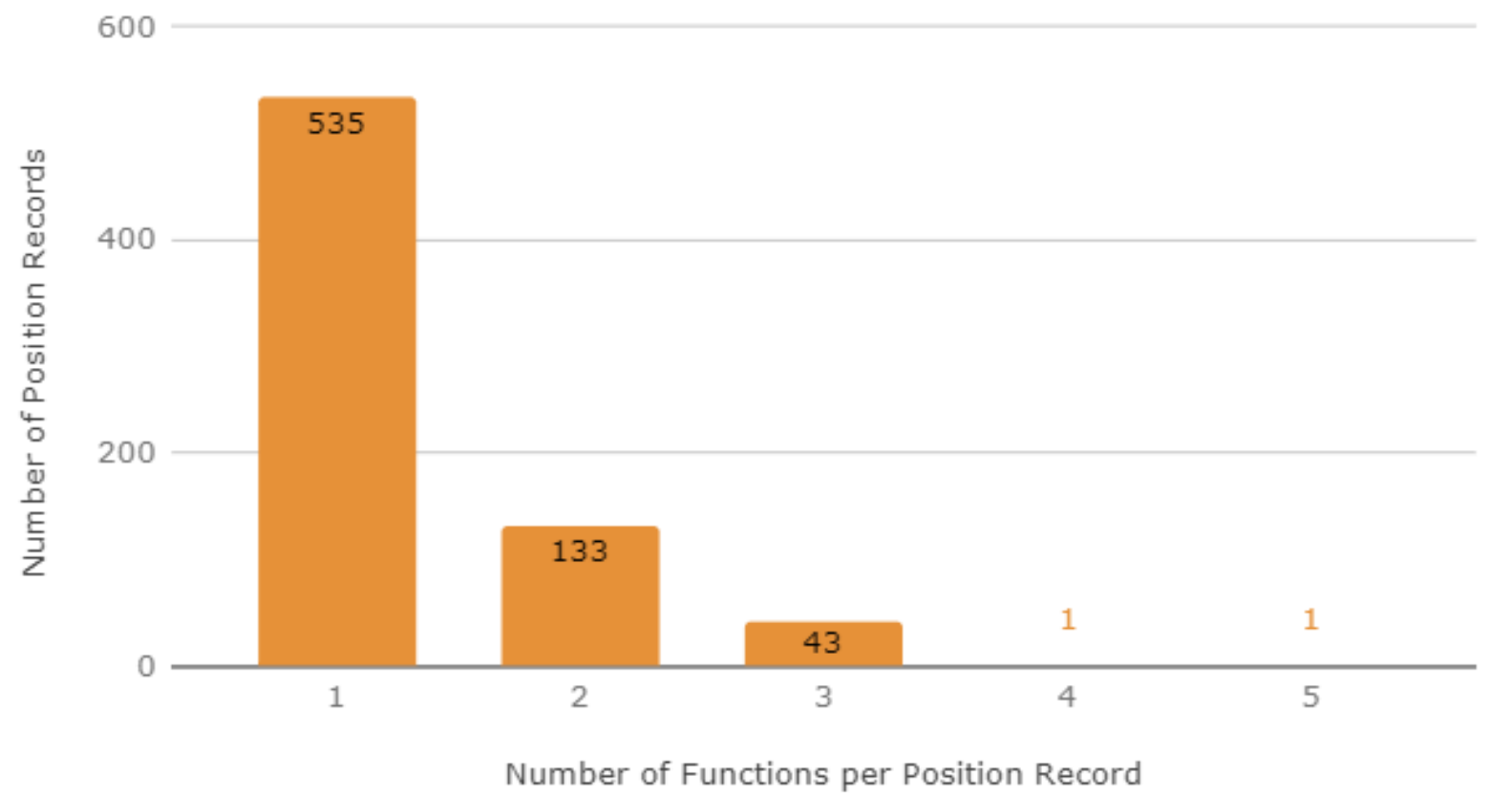

Table 3 displays the job functions that were more likely to occur in isolation than to be combined with other functions in support position records.

Table 3: Job functions in support positions more likely to occur in isolation

\begin{tabular}{|l|l|l|}
\hline Function & $\begin{array}{l}\text { \% of support positions with } \\
\text { functional isolation }\end{array}$ & $\begin{array}{l}\text { Total number of support } \\
\text { positions associated with } \\
\text { function }\end{array}$ \\
\hline Acquisitions & $68 \%$ & 66 \\
\hline Archiving/Curatorial/Rare Books & $87 \%$ & 47 \\
\hline $\begin{array}{l}\text { Cataloging/Bibliographic } \\
\text { Control/Metadata }\end{array}$ & $65 \%$ & 79 \\
\hline
\end{tabular}




\begin{tabular}{|c|c|c|}
\hline Function & $\begin{array}{l}\% \text { of support positions with } \\
\text { functional isolation }\end{array}$ & $\begin{array}{l}\text { Total number of support } \\
\text { positions associated with } \\
\text { function }\end{array}$ \\
\hline Clerical/Administrative Support & $61 \%$ & 41 \\
\hline $\begin{array}{l}\text { Communications/Public } \\
\text { Information }\end{array}$ & $56 \%$ & 9 \\
\hline Development/Fundraising & $75 \%$ & 8 \\
\hline Digital Services & $73 \%$ & 59 \\
\hline Electronic Resources & $71 \%$ & 24 \\
\hline Exhibits & $100 \%$ & 5 \\
\hline Facilities/Security & $84 \%$ & 31 \\
\hline Finance/Budget/Accounting & $75 \%$ & 24 \\
\hline Grants Management & $100 \%$ & 1 \\
\hline $\begin{array}{l}\text { Human } \\
\text { Resources/Organizational } \\
\text { Development }\end{array}$ & $60 \%$ & 15 \\
\hline Information Technology/Systems & $90 \%$ & 89 \\
\hline Media/Multi-Media Specialist & $65 \%$ & 20 \\
\hline Preservation/Conservation & $76 \%$ & 21 \\
\hline Press/Publishing & $78 \%$ & 9 \\
\hline Subject Specialist & $64 \%$ & 25 \\
\hline
\end{tabular}

Notably, no support position records were associated with the distance learning function.

\section{Management Positions}

Figure 3 displays the graphical output of the functional overlap among the 165 management position records included in our analysis. 
Figure 3: Gephi output of management position records

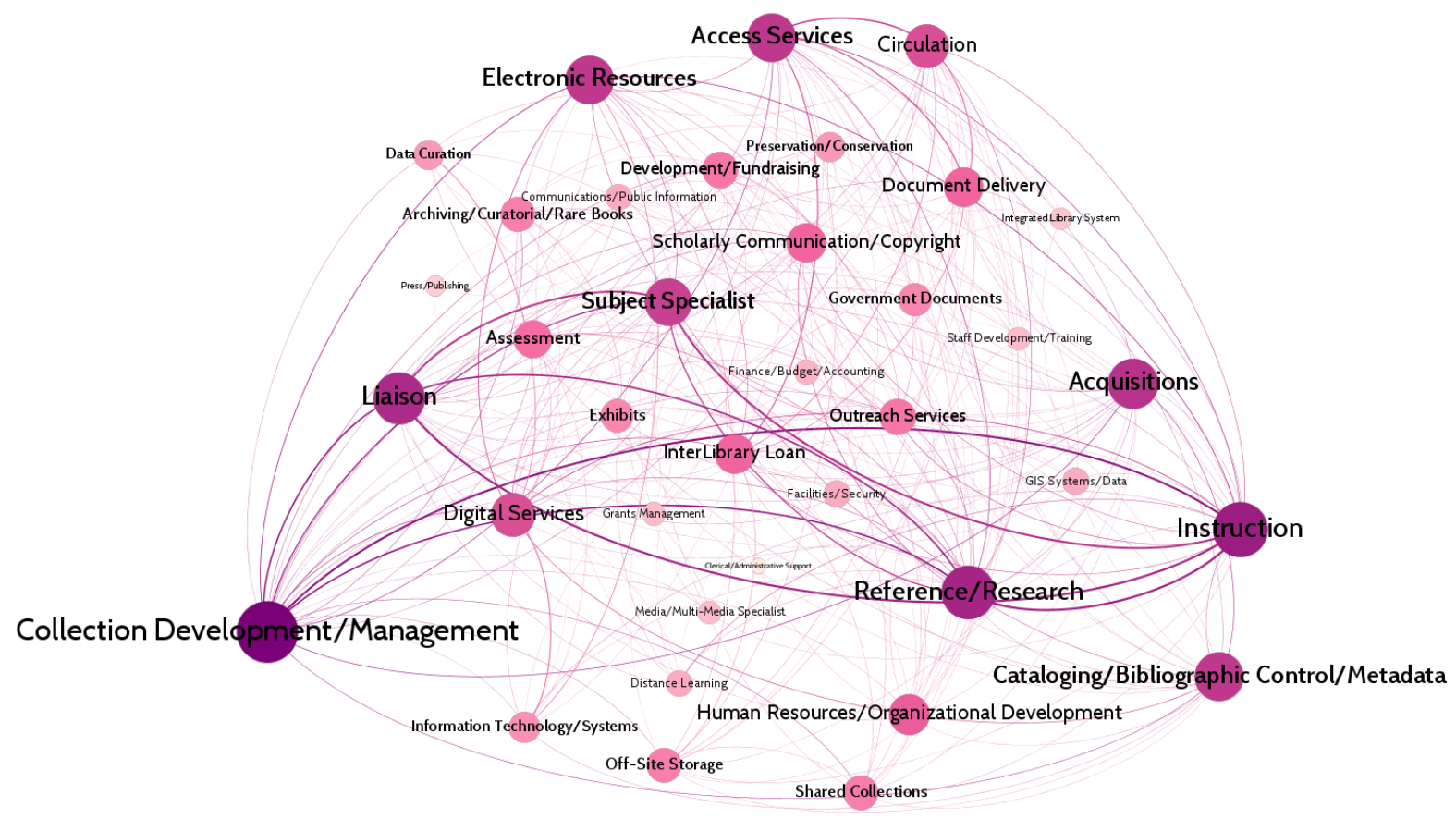

Co-occurrence is the measure of how frequently any two job functions were associated with the same position record in the PD Bank. The top 5 co-occurrences by count among all management position records were:

- Instruction and Liaison, co-occurring in 14 positions and with this co-occurrence relationship representing $54 \%$ of instruction positions and $61 \%$ of liaison positions.

- Instruction and Reference/Research, co-occurring in 14 positions and with this co-occurrence relationship representing $54 \%$ of instruction positions and $56 \%$ of reference/research positions.

- Collection Development and Instruction, co-occurring in 13 positions and with this co-occurrence relationship representing $46 \%$ of collection development positions and $50 \%$ of instruction positions.

- Instruction and Subject Specialist, co-occurring in 13 positions and with this co-occurrence relationship representing $50 \%$ of instruction positions and $45 \%$ of subject specialist positions.

- Liaison and Subject Specialist, co-occurring in 13 positions and with this co-occurrence relationship representing $57 \%$ of liaison positions and $45 \%$ of subject specialist positions.

In $44 \%$ of the 165 management position records included in our analysis, only one function was listed. In other words, 4 in 10 of the management position records analyzed for this study had a singular job focus and 6 in 10 had multiple coexisting functions (see Graph 3). 


\section{Graph 3: Management functional spread}

80

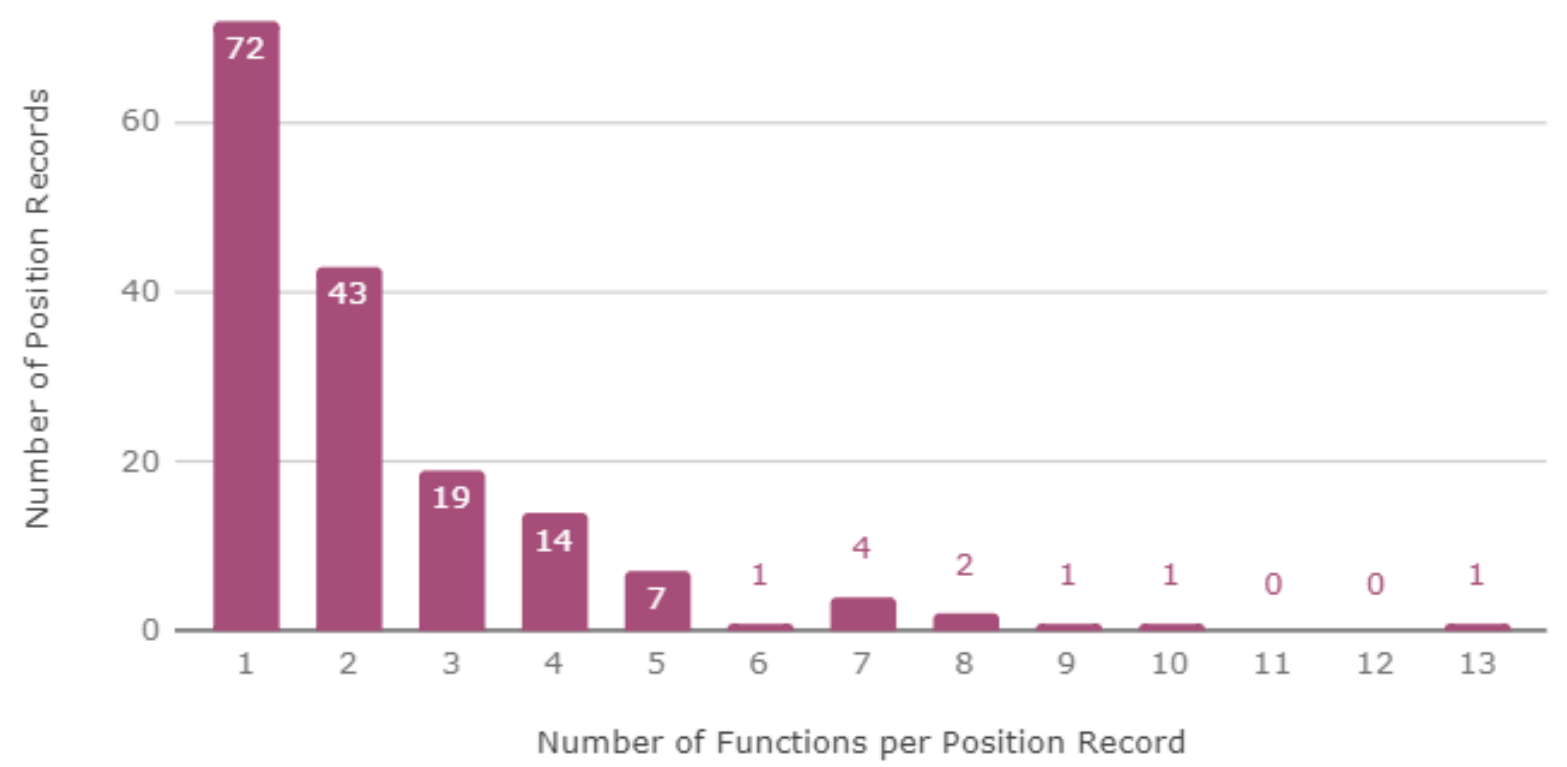

Table 4 displays the job functions that were more likely to occur in isolation than to be combined with other functions in management position records.

Table 4: Job functions in management positions more likely to occur in isolation

\begin{tabular}{|l|l|l|}
\hline Function & $\begin{array}{l}\text { \% of Management positions } \\
\text { with functional isolation }\end{array}$ & $\begin{array}{l}\text { Total number of Management } \\
\text { positions associated with } \\
\text { function }\end{array}$ \\
\hline $\begin{array}{l}\text { Cataloging/Bibliographic } \\
\text { Control/Metadata }\end{array}$ & $60 \%$ & 20 \\
\hline Media/Multi-Media Specialist & $71 \%$ & 7 \\
\hline
\end{tabular}

\section{Limitations}

Separating professional position records from support position records could mean splitting up functional areas that bridge both. Some functional-specific findings will only be found if we look at each functional areas separately with all the position records included.

The data set used in this analysis is limited to what was voluntarily shared in the PD Bank by users. Additionally, the metadata, critically including functional areas and position type entries for each position record, was submitted by users from various institutions. Any bias or self-selection resulting in the inclusion or exclusion of certain types of positions will limit the ability to characterize the state of library positions more broadly, based on this analysis. Similarly, any inconsistency, bias, or self-selection in regards to metadata selection will limit the generalizability of our findings.

\section{Discussion/Implications}

\section{Functional Spread}

The data suggest that the higher you climb in academic libraries, the more likely you are to be a unicorn.

Management positions were associated with anywhere between 1 and 13 functions, with an average of 2.35 
functions per position. Professional positions were associated with a narrower range, anywhere between 1 and 9 functions, with an average of 2.07 functions per position. Support positions were associated with the fewest functions, anywhere between 1 and 5 functions, with an average functional spread of 1.32. Further, management positions focus on just one functional area in $44 \%$ of position records, compared with professional positions where $50 \%$ of position records are associated with only one functional area. For support positions, $75 \%$ focused on just one functional area. These results are reflected in Graph 4.

\section{Graph 4: Functional spread by position type}

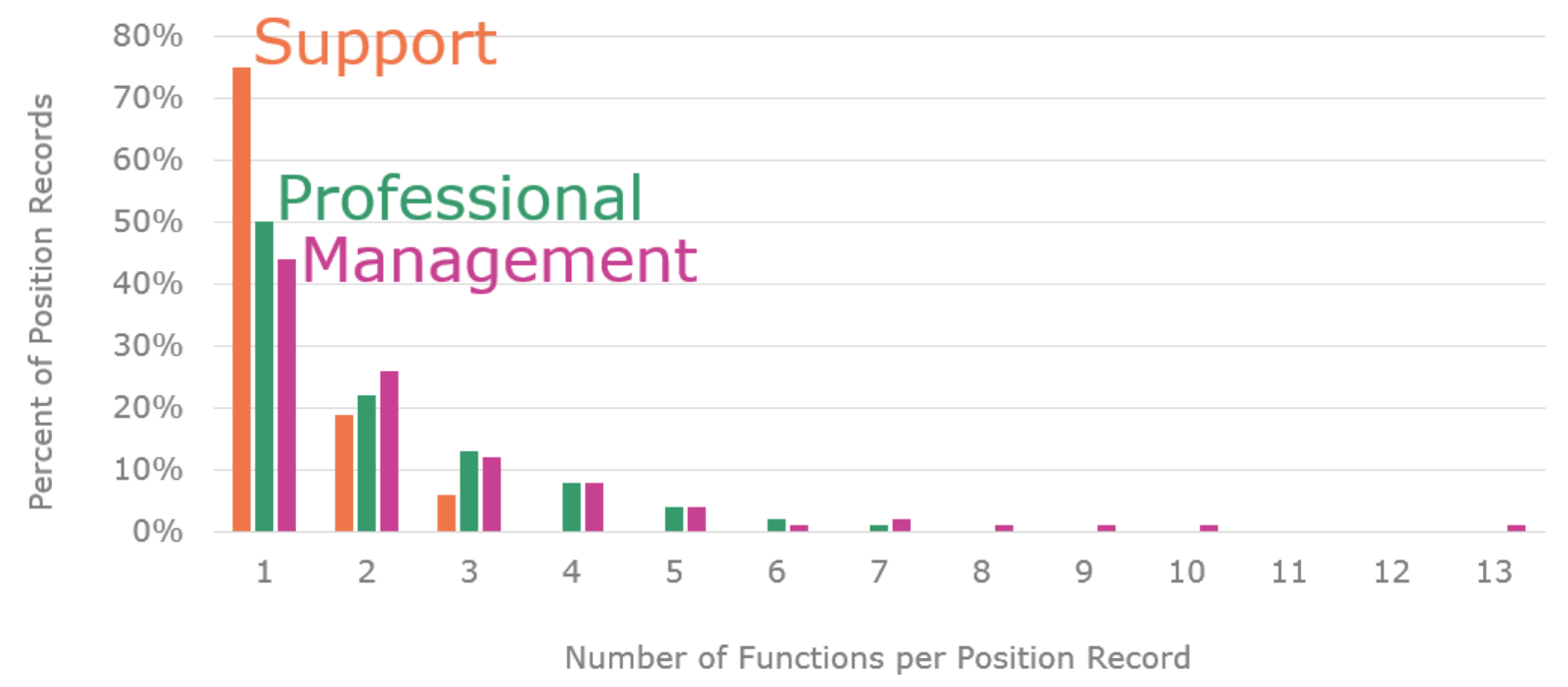

\section{Common Co-Occurrences}

Management positions, though they have the widest functional spread, are still most frequently associated with traditional librarian functions (e.g., instruction, liaison, collection development/management, subject specialist, and reference/research). For professional positions, the most common co-occurrences blended traditional librarian functions, e.g., reference/research, liaison, instruction, and subject specialist, in various combinations. For support positions, the most common co-occurrences blended traditional support functions: access services, InterLibrary loan, document delivery, acquisitions, cataloging/bibliographic control/metadata in various combinations.

\section{Future Steps}

This study relied on the data from the ARL PD Bank on February 28, 2018. As indicated above, we feel the data set was unique and potentially informative. In September 2018, a significant system enhancement was introduced where the job advertisements submitted to the ARL Job/Residency/Internship Listings website began to be ingested into the PD Bank, along with the submitted metadata. As of January 5, 2019, there are 2,119 position records in this system, including 197 that were ingested through this process. The recent enhancement will increase the size of this digital collection and the volume of associated metadata, supporting future research like that presented in this paper and other kinds, including text mining. Additionally, this automated collection process will reduce the impact of bias or self-selection resulting from the voluntary nature of active submissions to the PD Bank, discussed above.

The work presented here has generated what we feel are some interesting findings. Even if they may in some cases simply validate existing presumptions about library work, like higher level positions have broader scopes of responsibility, these presumptions may now be validated and can be built upon. Beyond the current findings, we feel that our work introduces an interesting methodological approach by applying network analysis to types of library work and using co-occurrences as the basis of analysis. We intend to expand on the work presented here. Potential future steps will include comparative analysis relying on additional PD 
Bank metadata fields at the position record level, beyond position type which was used here. These potential fields include appointment type (regular; tenure accruing or permanent; temporary/time limited; or residency/fellowship/internship) and library type (medical library; law library; non-university library; or all other). Are there distinctions between the co-occurrence rates for tenure accruing positions compared to other types of appointment? Do frequencies vary between library types, medical versus others? Beyond the position record level metadata comparisons, potential comparisons of co-occurrence could be made based on institutional characteristics, like staff size or public versus private status. Beyond these comparisons, the ARL PD Bank data will afford longitudinal comparisons. In these, one might track how relationships between job functions and the prevalence of unicorn positions evolves over time.

-Copyright 2019 Emily Guhde and Brian Keith 
Notes

1. Brian Keith, Bonnie Smith, and Laurie Taylor, "Building a Collaborative Position Description Archive as a Community of Practice," portal: Libraries and the Academy, 17, no. 2 (2017): 419-434, https://muse.jhu.edu/article/653214/pdf.

2. Barbara J. Dewey, ed., Transforming Research Libraries for the Global Knowledge Society (Oxford, U.K.: Chandos, 2010).

3. John Seely Brown, "Changing How We Think About and Lead Change," presentation at the Association of Research Libraries (ARL) Fall Forum, University of Southern California, Los Angeles, October 12, 2012, accessed November 4, 2018, http://www.slideshare.net/johnseelybrown/ff12-brown.

4. Lori A. Goetsch, "Reinventing Our Work: New and Emerging Roles for Academic Librarians," Journal of Library Administration 48, no. 2 (2008): 157-72, http://www.tandfonline.com/doi/abs/10.1080/01930820802231351.

5. Keith, Smith, and Taylor, "Building a Collaborative Position Description Archive as a Community of Practice," 421.

6. “Job Description," Merriam-Webster Dictionary, 2015, accessed November 4, 2018, http://www.merriamwebster.com/dictionary/job\%20description.

7. Keith, Smith, and Taylor, "Building a Collaborative Position Description Archive as a Community of Practice," 421.

8. Jeonghyun Kim, Edward Warga, and William Moen, "Competencies Required for Digital Curation: An Analysis of Job Advertisements," International Journal of Digital Curation 8, 1 (2013): 66-83, accessed November 4, 2018, http://dx.doi.org/10.2218/ijdc.v8i1.242; Antony Brewerton, “....and Any Other Duties Deemed Necessary': An Analysis of Subject Librarian Job Descriptions," SCONUL (Society of College, National and University Libraries) Focus 51 (2011): 60-67, http://www.sconul.ac.uk/sites/default/files/documents/18_2.pdf; Hanrong Wang, Yingqi Tang, and Carley Knight, "Contemporary Development of Academic Reference Librarianship in the United States: A 44-Year Content Analysis,” Journal of Academic Librarianship 36, no. 6 (2010): 489-94, http://dx.doi.org/10.1016/j.acalib.2010.08.004; Linda Marion, "Digital Librarian, Cybrarian, or Librarian with Specialized Skills: Who Will Staff Digital Libraries?" in Crossing the Divide: Proceedings of the ACRL (Association of College and Research Libraries) 10th National Conference, March 15-18, 2001, Denver, CO, Hugh A. Thompson, ed. (Chicago: American Library Association, 2001), 143-49, http://www.ala.org/acrl/sites/ala.org.acrl/files/content/conferences/pdf/marion.pdf; Tito Sierra, "Staffing for the Future: ARL (Association of Research Libraries) University Library Hiring in 2011," poster presentation at ARL Leadership and Career Development Program, June 2012, accessed November 4, 2018, http://www.arl.org/storage/documents/publications/lcdp-2012-poster-sierratito.pdf.

9. Youngok Choi and Edie Rasmussen, "What Qualifications and Skills Are Important for Digital Librarian Positions in Academic Libraries? A Job Advertisement Analysis," Journal of Academic Librarianship 35, 5 (2009): 457-67, http://dx.doi.org/10.1016/j.acalib.2009.06.003; Craig Finlay, Andrew Tsou, and Cassidy R. Sugimoto, "Scholarly Communication as a Core Competency: Prevalence, Activities, and Concepts of Scholarly Communication Librarianship as Shown through Job Advertisements," Journal of

Librarianship and Scholarly Communication 3, no. 1 (2015): 8, http://jlsc-pub.org/articles/abstract/ 10.7710/2162-3309.1236/; Jingfeng Xia and Minglu Wang, "Competencies and Responsibilities of Social Science Data Librarians: An Analysis of Job Descriptions," College \& Research Libraries 75, 3 (2014): $362-$ 88, http://crl.acrl.org/content/75/3/362.full.pdf+html; John D. Shank, "The Blended Librarian: A Job Announcement Analysis of the Newly Emerging Position of Instructional Design Librarian,” College \& Research Libraries 67, 6 (2006): 514-24, http://crl.acrl.org/content/67/6/514.full.pdf+html; Tara Radniecki, "Study on Emerging Technologies Librarians: How a New Library Position and Its Competencies Are Evolving to Meet the Technology and Information Needs of Libraries and Their Patrons," presentation at International Federation of Library Associations and Institutions (IFLA), World Library and Information Congress, Singapore, 2013, accessed November 4, 2018, http://library.ifla.org/134/1/152-radniecki-en.pdf. 
10. Therese F. Triumph and Penny M. Beile, "The Trending Academic Library Job Market: An Analysis of Library Position Announcements from 2011 with Comparisons to 1996 and 1988," College \& Research Libraries 76, 6 (2015): 716-39, http://crl.acrl.org/content/76/6/716.full.pdf+html.

11. Triumph and Beile, "The Trending Academic Library," 735.

12. Triumph and Beile, "The Trending Academic Library," 735.

13. Keith, B., Smith, B., Taylor, L., Sullivan, L., \& the Association of Research Libraries, "ARL Position Description Bank Project," accessed January 16, 2016, http://uflib.ufl.edu/arlpdbank/.

14. L. Duranti, "From Digital Diplomatics to Digital Records Forensics," Archivaria 68 (2009): 39. 


\section{Appendix A}

When creating a position record, institutional users are required to identify the main functional area(s) for each position. This user activity not only provides useful search criteria but also important data on the frequency and, over time, the evolution of positions within academic libraries. The following table depicts all functional areas available in the ARL PD Bank and the number of instances of records for which the functional area was selected, as of January 28, 2017.

Table 5: Functional area occurrences in the ARL PD Bank as of January 28, 2017

\begin{tabular}{|c|c|}
\hline Functional area & Number of instances within ALL records \\
\hline Reference/Research & 224 \\
\hline Subject Specialist & 221 \\
\hline Branch/Unit/Department Management & 162 \\
\hline Cataloging/Bibliographic Control/Metadata & 162 \\
\hline Information Technology/Systems & 150 \\
\hline Digital Services & 133 \\
\hline Circulation & 130 \\
\hline Instruction & 128 \\
\hline Archiving/Curatorial/Rare Books & 123 \\
\hline Liaison & 117 \\
\hline Collection Development/Management & 116 \\
\hline Access Services & 111 \\
\hline Acquisitions & 94 \\
\hline Electronic Resources & 64 \\
\hline Senior Management & 57 \\
\hline Outreach Services & 45 \\
\hline Preservation/Conservation & 44 \\
\hline Clerical/Administrative Support & 43 \\
\hline Document Delivery & 43 \\
\hline InterLibrary Loan & 41 \\
\hline Media/Multi-Media Specialist & 34 \\
\hline Facilities/Security & 32 \\
\hline
\end{tabular}




\begin{tabular}{|l|l|}
\hline Functional area & Number of instances within ALL records \\
\hline Finance/Budget/Accounting & 32 \\
\hline Communications/Public Information & 30 \\
\hline Human Resources/Organizational Development & 27 \\
\hline Data Curation & 26 \\
\hline Shared Collections & 25 \\
\hline Scholarly Communication/Copyright & 24 \\
\hline Development/Fundraising & 23 \\
\hline Assessment & 22 \\
\hline Exhibits & 19 \\
\hline Staff Development/Training & 17 \\
\hline Off-Site Storage & 16 \\
\hline Distance Learning & 15 \\
\hline Press/Publishing & 15 \\
\hline Government Documents & 14 \\
\hline Integrated Library System & 13 \\
\hline GIS Systems/Data & 5 \\
\hline Grants Management & 22 \\
\hline
\end{tabular}

